\title{
Quantification of trace elements in raw cow's milk by inductively coupled plasma mass spectrometry (ICP-MS)
}

\author{
A. Ataro, R.I. McCrindle, B.M. Botha, C.M.E. McCrindle, P.P. Ndibewu
}

Tshwane University of Technology, Department of Chemistry, P.O. Box 56208, Arcadia 0007, South Africa

University of Pretoria, Department of Paraclinical Sciences, Section Veterinary Public Health, Private Bag x04, Onderstepoort 0110, South Africa

\begin{abstract}
The levels of trace elements are an important component of safety and quality of milk. While certain elements such as chromium are essential at low levels, an excess can result in deleterious effects on human health. International quality control standards for milk are published by the Codex Alimentarious Commission and levels of heavy metals in milk intended for human consumption are routinely monitored. This paper describes a new method for demonstrating the levels of $\mathrm{V}, \mathrm{Cr}, \mathrm{Mn}, \mathrm{Sr}, \mathrm{Cd}$ and $\mathrm{Pb}$ in raw cow's milk, using an ICP-MS. Samples $(n=24)$ of raw cow's milk were collected from dairy farms close to mines in Gauteng and North West Provinces of South Africa. In order to destroy organic matrix, each freeze dried milk sample was mineralised by using a microwave assisted digestion procedure. Concentrations of trace elements in digested milk samples were measured by ICP-MS. A whole milk powder reference material (NIST SRM 8435) was used to evaluate the accuracy of the proposed method. It was found that the levels of $\mathrm{V}, \mathrm{Cr}, \mathrm{Mn}, \mathrm{Sr}, \mathrm{Cd}$ and $\mathrm{Pb}$ obtained using the new method showed concordance with certified values.
\end{abstract}

\section{Introduction}

Milk is recognized as an almost complete food product in the human diet because it provides all macronutrients (such as proteins, lipids and carbohydrates) and all micronutrients (elements, vitamins and enzymes) (http://www.idfa.org/facts/milk/milkfact/milk5.pdf). This fact is particularly true in the case of early childhood, because milk (human, cow or formula) is the only source of nutrients during the first months of a baby's life and the diet of growing children contains a high proportion of milk and milk products. An appropriate intake of milk is also recommended for adults as a source of calcium to retain bone mass so that fractures and osteoporosis can be prevented (Kira \& Maio, 2004).

The trace elements in cow's milk are of interest because of their essential or toxic nature. For instance, $\mathrm{Cr}$ and $\mathrm{Mn}$ are essential but may become toxic at higher levels, while $\mathrm{Pb}$ and $\mathrm{Cd}$ are toxic and can be cumulative (Martino, Sánchez, \& Medel, 2000; Onianwa, Adetola, Iwegbue, Ojo, \& Tella, 1999; Underwood, 1977). Cd and $\mathrm{Pb}$ are amongst the elements that have caused most concern in terms of adverse effects on human health. This is because they are readily transferred through food chains and are not known to serve any essential biological function (Liu, 2003). Children have been shown to be more sensitive to $\mathrm{Cd}$ and $\mathrm{Pb}$ than adults andthe effects are cumulative, the elements build up in the tissues (Tripathi, Raghunath, Sastry, \& Krishnamoorthy, 1999). As a result, the regular absorption of small amounts of elements such as $\mathrm{Pb}$ may cause serious effects on the health of growing children, including retardation of mental development (e.g. reading and learning disabilities) and deficiencies in concentration, adverse effects on kidney function, blood chemistry and the cardiovascular system, as well as hearing degradation (Salma, Maenhaut, Dubtsov, Papp, \& Záray, 2000). It is therefore important to monitor the levels of trace elements in cow's milk, which forms a major source of nutrition in childhood, consumed with breakfast cereals and as yoghurt or cheese.

The concentrations of selected trace elements such as $\mathrm{Al}, \mathrm{Ba}, \mathrm{Cd}, \mathrm{Co}, \mathrm{Cr}, \mathrm{Cu}, \mathrm{Fe}, \mathrm{Mg}, \mathrm{Mn}$, $\mathrm{Ni}, \mathrm{Pb}, \mathrm{Pt}, \mathrm{Sr}$ and $\mathrm{Zn}$ in raw cow's milk and cheese were determined using inductively coupled plasma-optical emission spectrometry after lyophilisation followed by ashing (Coni, Bocca, lanni, \& Caroli, 1995; Coni, Caroli, lanni, \& Bocca, 1994). Coni et al. (1996) later assessed the concentrations of the same elements in sheep and goats milk as well as in cheese employing the same method. The determination of $\mathrm{Ca}, \mathrm{Cu}, \mathrm{Fe}, \mathrm{K}, \mathrm{Mg}, \mathrm{Mn}, \mathrm{Na}, \mathrm{P}$ and $\mathrm{Zn}$ in infant formulae, milk powders and liquid milk by slurry nebulisation and inductively coupled 
plasma-optical emission spectrometry were described by McKinstry, Indyk, and Kim (1999). Trace concentrations of $\mathrm{Cd}, \mathrm{Pb}$ and $\mathrm{Cu}$ in milk were subsequently determined by potentiometric stripping analysis using a home-made flow cell after ashing (Muñoz \& Palmero, 2004).

Caggiano et al. (2005) measured $\mathrm{Cd}, \mathrm{Cr}, \mathrm{Hg}, \mathrm{Mn}$, and $\mathrm{Pb}$ levels in samples of fodder, sheep's milk, dairy products, and tissues collected from 12 ovine farms in the regions of Campania and Calabria (Southern Italy). Al-Awadi and Srikumar (2000) reported the concentration of Zn, $\mathrm{Cu}, \mathrm{Mn}$, and $\mathrm{Fe}$ in milk and plasma of Kuwaiti and non-Kuwaiti mothers during prolonged lactation. Studies in determination of $\mathrm{Pb}$ concentration in human milk were conducted by a number of authors (Saleh, Ragab, Kamel, Jones, \& El-Sebae, 1996; Sowers et al., 2002). Smit, Schönfeldt, de Beer and Smith (2000) investigated the effect of locality and season on the nutrient composition of South African cow's milk. Milk samples were collected from Gauteng, KwaZulu-Natal, Free State, Eastern Cape and Western Cape. The study focused on analysis of protein, lactose, fat, moisture, total solids, ash, energy, chloride, phosphorus, sodium, potassium, magnesium, calcium and vitamins.

International standard methods for the analysis of some elements in milk and milk products are well documented. These include determination of lead in evaporated milk by atomic absorption spectrometry after dry ashing and extraction with 1- pyrrolidinecarbodithioate, and by anodic stripping voltammetry after dry ashing and dissolving the residue in $\mathrm{HNO}_{3}(\mathrm{AOAC}$, 1990). The Codex Alimentarius Commission recommended method AOAC 972.25, is for the evaluation of lead levels in butter, edible casein products and whey powders (Codex Alimentarius Commission, 1998). In that method, the final quantification of lead is conducted by atomic absorption spectrometry. Iron in milk products is evaluated by atomic absorption spectrometry after dry ashing (Codex Alimentarius Commission, 1998).

ICP-MS has become accepted as the most powerful analytical tool for the simultaneous determination of trace elements due to its extreme sensitivity, selectivity and capability of multi elemental and isotopic analysis. Martino et al. (2000) analysed essential and toxic elements in milk whey using a double focusing ICP-MS after dilution with ultrapure water. Milk elemental analysis by direct nebulisation of aqueous solutions is hampered by blockage of cones, deposition of organic matter in the injector tube of the torch, and spectral and nonspectral interferences due to the fatty nature of the matrix. The use of a high resolution mass spectrometer such as a double focusing ICP-MS reduces the influence of spectral interferences. Although, the double focusing ICP-MS offers the advantage of high resolving power, it is significantly slower than the quadrupole based ICP-MS. With the increasing demand for analyses required by public health programmes and private companies, it is important to use a quadrupole ICP-MS for routine, high-throughput trace element analyses. This study involved the development of an alternative method for the evaluation of selected trace elements in raw cow's using ICP-MS after lyophilisation of milk samples by a freezedrying unit followed by microwave digestion. Lyophilisation allows the quick destruction of organic matrix and pre-concentration of analyte by minimising dilution.

The primary objective of this study is to contrast the efficiency of the method developed for the evaluation of $\mathrm{V}, \mathrm{Cr}, \mathrm{Mn}, \mathrm{Sr}, \mathrm{Cd}$ and $\mathrm{Pb}$ with the results obtained from certified reference materials in order to validate the method. Field samples were analysed to further validate the method.

\section{Experimental}

\subsection{Apparatus}

A LP3 model freeze dryer (Jouan, France) was used to dry liquid milk samples. The MARS 5 microwave digestion system (CEM Corporation, USA) was employed for mineralisation of freeze-dried milk samples. A Teflon XP-1500 Plus Vessel, allowing maximum decomposition pressure of $800 \mathrm{psi}$ and temperature of $240^{\circ} \mathrm{C}$, was used for digestion. The High Pressure Digestion Vessel Accessory Sets (CEM Corporation, USA) permit simultaneous processing of up to 12 XP-1500 Plus vessels. At full power, the MARS delivers approximately 1200 watts of microwave energy at a magnetron frequency of $2450 \mathrm{MHz}$. All glassware was washed with detergent and water. After being rinsed with de-ionised water $(18.2 \mathrm{MX} \mathrm{cm})$ three times, it was soaked in $10 \% \mathrm{HNO}_{3}(\mathrm{v} / \mathrm{v})$ for $24 \mathrm{~h}$. This solution was discarded and the glassware was soaked again in $10 \% \mathrm{HNO}_{3}(\mathrm{v} / \mathrm{v})$ for $24 \mathrm{~h}$. The glassware was then rinsed three times with deionised water with a resistivity of $18.2 \mathrm{M} \Omega \mathrm{cm}$, and dried. 


\subsection{Instrumentation}

ICP-MS measurements were performed by a quadrupole ELAN DRC-e spectrometer (PerkinElmer SCIEX, Concord, Ontario, Canada), equipped with a PerkinElmer auto sampler model AS-93 Plus and with as93f.try tray. A cross-flow nebuliser with a Scott type double pass spray chamber sample introduction system was employed in this study. Details on the instrumentation and the operating conditions are summarised in Table 1.

\subsection{Reagents}

All solutions were prepared using ultra-pure reagents. The water used in this work was doubly de-ionised with the final stage of de-ionisation provided by a Milli- $Q$ water purification system (Millipore, Bedford, MA, USA). High purity $\mathrm{HNO}_{3}(65 \%$, Suprapur, Merck, Darmstadt, Germany) was used for cleaning glassware and digesting milk samples throughout this work. A stock standard solution containing $1000 \mathrm{mg} / \mathrm{L}$ of each element (TEKNOLAB A/S, Kolbotn, Norway) was used in preparing calibration standards. The calibration solutions were prepared from the stock solution using de-ionised water $(18.2 \mathrm{MX} \mathrm{cm})$ immediately before analysis. An internal standard solution containing $10 \mathrm{mg} / \mathrm{L}$ of each of $\mathrm{Ga}$, In and $\mathrm{Tl}$ was prepared from single-element standard solutions (1000 mg/L) (TEKNOLAB A/S, Kolbotn, Norway). The mass calibration stock solution containing $\mathrm{Ba}, \mathrm{Be}, \mathrm{Ce}, \mathrm{Co}, \mathrm{In}, \mathrm{Mg}, \mathrm{Pb}, \mathrm{Rh}$ and $\mathrm{U}$ at $10 \mathrm{lg}$ element/L was obtained from PerkinElmer (Concord, Ontario, Canada). Argon (N 4.8) of $99.998 \%$ purity was supplied by Afrox Boc gases (Afrox, South Africa).

A whole milk powder reference material (NIST SRM 8435, Gaithersburg, MD, USA) was employed to evaluate the accuracy and precision of the final quantification of elemental concentration of milk samples.

\subsection{Standards}

Standard solutions were prepared daily by appropriate dilution of stock standard $1000 \mathrm{mg} / \mathrm{L}$ each element. Quantification of trace element concentrations were performed, establishing calibration curves with external standards prepared in $1 \% \mathrm{v} / \mathrm{v}$ ultrapure $\mathrm{HNO}_{3}$ for analysis of all samples. The calibration curve was made from four points and the blank.

\subsection{Sampling}

Convenience sampling was used to select eight dairies in the proximity of mines in order to increase the likelihood of finding the elements of interest in cow's milk. All samples of raw cow's milk $(250 \mathrm{ml})$ were collected during the morning milking. Three milk samples from each site were collected from the bulk milk tanks. The sampling procedure was in strict adherence to the International Dairy Federation (IDF) standard methods of sampling for bulk milk (Smit et al., 2000). The milk samples were collected in $250 \mathrm{ml}$ glass bottles from the bulk tank on each farm and immediately placed in a cooler box. On arrival at the laboratory, about $40 \mathrm{~g}$ of the liquid milk was placed in a $250 \mathrm{~mL}$ volumetric flask. The milk samples were stored at $-20^{\circ} \mathrm{C}$ in a deep freeze (CHEST FREEZER DEFY 270L MM (G) model, DEFY, South Africa). Each 40 $\mathrm{g}$ sample was freeze dried using a LP 3 freeze drying unit (Jouan, France). Three replicate determinations were carried out on each sample. Thus, a total of $24 \times 3=72$ samples were analysed.

\subsection{Sample preparation}

\subsubsection{Lyophilisation and crushing of milk samples}

The frozen samples were placed in a LP3 freeze-drying unit for $31 \mathrm{~h}$, until a constant mass was achieved. This operation greatly expedited the subsequent mineralisation of the organic matrix, while at the same time it allowed dilution to be minimised. The dried milk was crushed with the tip of a plastic stirrer until a fine powder was obtained and mixed thoroughly to maintain the homogeneity.

\subsubsection{Microwave assisted acid digestion of milk samples}


The microwave assisted digestion procedure was adopted for the mineralisation of milk samples after some preliminary attempts. This procedure consumed a lesser volume of reagent and shorter digestion time. A powdered milk sample aliquot of $0.5 \mathrm{~g}( \pm 0.0001)$ was accurately weighed and quantitatively transferred to each XP-1500Plus vessel. The sample was reconstituted with $2 \mathrm{ml}$ of $18.2 \mathrm{M} \Omega \mathrm{cm}$ de-ionised water. Then $4 \mathrm{ml}$ of $65 \% \mathrm{HNO}_{3}$ (Suprapur, Merck, Darmstadt, Germany) was added to each sample and the vessels were allowed to stand open until the initial reaction subsided. The samples were mineralised in the MARS 5 microwave digestion system (CEM Corporation, USA) employing the following programme: pressure control, $10 \mathrm{~min}$ ramp, 20 min hold, maximum pressure $500 \mathrm{psi}$ and maximum temperature $200^{\circ} \mathrm{C}$. A blank solution was prepared by digesting $2 \mathrm{ml}$ of $18.2 \mathrm{MX}$ $\mathrm{cm}$ deionised water and $4 \mathrm{ml}$ of $65 \% \mathrm{HNO} 3$ using the same digestion procedure. The digested samples and reagent blank were diluted to $25 \mathrm{ml}$. All digestions were prepared in triplicate.

All vessels were automatically cooled for $20 \mathrm{~min}$ following the completion of the digestion program. The pressure was vented and vessel covers were removed. After mineralisation, the samples were quantitatively transferred to $25 \mathrm{ml}$ volumetric flasks and brought up to the mark with ultra pure de-ionised water. Blanks, consisting of de-ionised water and reagents were subjected to a similar sample preparation and analytical procedure.

\subsubsection{Cleaning procedure for vessels}

Cleaning of digestion vessels was conducted in the microwave digestion system using two $\mathrm{ml}$ of de-ionised water and four $\mathrm{ml}$ of $65 \% \mathrm{HNO}_{3}$, as required for sample preparation, following the heating program: $15 \mathrm{~min}$ ramp from ambient temperature to $200^{\circ} \mathrm{C}$, holding for $8 \mathrm{~min}$. The pressure was programmed at $100 \mathrm{psi}$. After cooling, the acid residues were discarded. Then vessels were thoroughly rinsed with de-ionised water and dried in the oven at $100{ }^{\circ} \mathrm{C}$ over night before next use.

\subsection{Sample analysis}

Trace element concentrations in milk samples were estimated using the ELAN DRC-e ICPMS instrument equipped with a cross flow nebuliser, nickel cones and a peristaltic sample delivery tube. Before each measurement series, the instrument had undergone 45-60 min routine conditioning and optimisation procedure. The operating conditions for ICP-MS measurements were optimised daily, by monitoring signals produced by a multi elemental solution containing $10 \mu \mathrm{g} / \mathrm{L} \mathrm{Ba}, \mathrm{Be}, \mathrm{Ce}, \mathrm{Co}, \mathrm{In}, \mathrm{Mg}, \mathrm{Pb}, \mathrm{Rh}$ and $\mathrm{U}$ in the Graphics mode of analysis. The selected conditions were those, which maximize ${ }^{115} \mathrm{In}$ and equal ${ }^{24} \mathrm{Mg}$ and ${ }^{208} \mathrm{~Pb}$ signals.

Concentrations of trace elements in digested milk samples were determined using an external calibration curve. Blank, standard and milk sample solutions were nebulised and each solution of standard or sample was followed by introduction of de-ionised water for at least 1 $\mathrm{min}$, to rinse the sampling system in order to avoid contamination of other solutions. Three independent replicates of each sample were measured, and the concentrations were calculated using the average of each value. The blank samples were also measured, and intensity of each analyte in the blank sample was subtracted from that of the sample.

\subsection{Quality assurance/quality control performance}

For the assessment of the accuracy of the concentration of trace elements determined in milk samples, a whole milk powder reference material (NIST SRM 8435, Gaithersburg, MD, USA), was used.

\subsection{Statistical analysis}

The data was analysed using one-way analysis of variance (ANOVA) to examine statistical significance of differences in the mean concentration of $\mathrm{V}, \mathrm{Cr}, \mathrm{Mn}, \mathrm{Sr}, \mathrm{Cd}$, and $\mathrm{Pb}$, determined in milk samples. A probability level of $P=0.05$ was considered statistically significant. The SAS system for windows V8 software was employed for statistical analysis (SAS Institute Inc., 2001).

\section{Results and discussion}




\subsection{Selection of isotopes}

The development of a method for the determination of trace elements $(\mathrm{V}, \mathrm{Cr}, \mathrm{Mn}, \mathrm{Sr}, \mathrm{Cd}$ and $\mathrm{Pb}$ ) entails careful selection of isotopes for monitoring their concentrations in milk samples. The possible interferences caused by the milk matrix on the signal of each considered mass, should be investigated. When the element of interest had two or more isotope masses, at least two isotopes per element were monitored. The selected isotopes were the most abundant for each element, which showed less interferences from the matrix. The following isotopes were selected for simultaneous monitoring: ${ }^{51} \mathrm{~V},{ }^{52,53} \mathrm{Cr},{ }^{55} \mathrm{Mn},{ }^{86,87,88} \mathrm{Sr},{ }^{110,111,114} \mathrm{Cd}$ and ${ }^{206,207,208} \mathrm{~Pb}$. The software was programmed in order to apply the corresponding correction equations.

\subsection{Choice of internal standard}

It is well known that the nature and concentration of the sample matrix has a direct influence on suppression or an enhancement of the true analyte signals. The ICP-MS internal standardisation is an effective way of compensating for instrument instability and/or signal drift and matrix effects (Evans \& Giglio, 1993; Vanhaecke, Vanhoe, \& Dams, 1992). Careful selection of the internal standard is necessary in order to overcome the presence of matrix interferences and instrumental drift. The internal standard should closely match the analyte element(s) in terms of mass number and ionization potential, so that possible interferences do not disturb the relationship between analyte and internal standard signals used for final determinations (Evans \& Giglio, 1993; Martino, Sánchez, \& Sanz-Medel, 2001; Martino et al., 2000; Melaku, Wondimu, Dams, \& Moens, 2004). Using an internal standard with a mass number close to that of the analyte also improves the precision (Vanhaecke et al., 1992).

The internal standards must be added to the sample, calibration standards and blank solutions at the same concentration level. Since the analyte elements are spread over a wide range of atomic masses, three internal standards, ${ }^{69} \mathrm{Ga},{ }^{11} 5 \mathrm{In}$ and ${ }^{205} \mathrm{TI}$ were selected for $\mathrm{V}$, $\mathrm{Cr}$ and $\mathrm{Mn} ; \mathrm{Sr}$ and $\mathrm{Cd}$; and $\mathrm{Pb}$, respectively. The digested cow's milk samples, a reference whole milk powder, blanks and calibration standards were spiked with the internal standard solution to obtain a final concentration of $10 \mu \mathrm{g} / \mathrm{L}$ in each internal standard ( $\mathrm{Ga}$, In and $\mathrm{TI})$. Using these internal standards allowed accurate and precise determination of the analytes in SRM 8435. Therefore, external calibration with internal standards was employed for quantitation of trace elements in milk samples. The analyte isotopes eventually used for final measurements were: ${ }^{51} \mathrm{~V},{ }^{52} \mathrm{Cr},{ }^{55} \mathrm{Mn},{ }^{88} \mathrm{Sr},{ }^{111} \mathrm{Cd}$ and ${ }^{208} \mathrm{~Pb}$, because they are the most abundant non-interfered isotopes and thus provide better results.

\subsection{Detection limit $(D L)$}

Reagent blanks were prepared following the same procedure for the digestion of freeze-dried milk. The intensities of 10 blanks were measured. Standard deviations were calculated from the intensity readings of these 10 blanks. The detection limits for each element under study, based on three times the standard deviation of the average of 10 individually prepared blank solutions, are given in Table 2.

Detection limits of $0.03,0.05,0.20,0.04$ and $0.15 \mu \mathrm{g} / \mathrm{L}$ were reported for $\mathrm{Cr}, \mathrm{Mn}, \mathrm{Sr}, \mathrm{Cd}$ and $\mathrm{Pb}$, in milk whey using a double focusing ICP-MS (Martino et al., 2000). The calculated detection limits were found to be lower than these values for $\mathrm{Sr}, \mathrm{Cd}$ and $\mathrm{Pb}$. Where as the detection limits of $\mathrm{Cr}$ and $\mathrm{Mn}$ using our method were higher than the above value. Martino et al. (2001) also reported detection limits of $0.21,0.90,2.2,0.25$ and $0.92 \mathrm{for} \mathrm{Cr}, \mathrm{Mn}, \mathrm{Sr}, \mathrm{Cd}$ and $\mathrm{Pb}$, respectively, in their studies of elemental patterns in whole milk, skimmed milk and milk whey using double focusing ICP-MS. These values are 2.12, 8.74, and 13.5, 41.7 and 6.76 times higher than detection limits obtained by our method for $\mathrm{Cr}, \mathrm{Mn}, \mathrm{Sr}, \mathrm{Cd}$ and $\mathrm{Pb}$, respectively.

In the absence of polyatomic interferences, the level of a selected isotope for a given element had a great influence on the detection limits of the particular element. The greater the abundance, the lower the detection limit (Martino et al., 2000).

\subsection{Validation}


A reference whole milk powder (NIST SRM 8435, Gaithersburg, MD, USA) was analysed to test the accuracy of the proposed method. The results obtained for the analysis of the certified reference material by ICP-MS are shown in Table 2 along with certified values. The results were generally in good agreement with NIST certified values, indicating validity of our method for analysis of milk samples. The level of $\mathrm{Cd}$ in whole milk powder reference material was too low and below the detection limit of the method. The certified value for $V$ is not available in SRM 8435.

\subsection{Total concentration of trace elements in samples}

Total concentrations of trace elements in milk samples were measured by ICP-MS. Three different milk samples were analysed from each sampling site. Table 3 presents the total concentration of trace elements (expressed in dry weight) for 24 milk samples analysed. $\mathrm{V}, \mathrm{Cr}, \mathrm{Mn}$ and $\mathrm{Sr}$ were detectable in all the samples and their concentrations ranged from 23.4 to $42.0,186$ to 371,109 to 299 and 1880 to $3150 \mathrm{ng} / \mathrm{g}$, respectively. The concentrations of $\mathrm{Cr}$ obtained in this study were comparable to those from Italy (Coni et al., 1995), whereas Mn levels were relatively higher than that reported from Italian cow's milk (Coni et al., 1995). Sr levels as high as $10.1 \mu \mathrm{g} / \mathrm{g}$ were reported (Coni et al., 1995) in raw cow's milk.

$\mathrm{Cd}$ was not detected in any of the samples. This indicates the absence of $\mathrm{Cd}$ related toxicological risks in studied farms. Pb was detectable in milk samples from three dairy farms (1, 3 and 5$). \mathrm{Pb}$ concentrations in milk samples collected from these farms ranged from 8.00 to $19.7 \mathrm{ng} / \mathrm{g}$. Pb levels as high as $0.138 \mu \mathrm{g} / \mathrm{g}$ were detected by Coni et al. (1995) in Italian cow's milk samples. Martino et al. (2000) recorded $0.9 \mathrm{mg} / \mathrm{L} \mathrm{Pb}$ in cow's milk whey by using a double focusing ICP-MS. More recently, Swarup, Patra, Naresh, Kumar and Shekhar (2005) quantified a $\mathrm{Pb}$ level of $0.84 \mathrm{mg} / \mathrm{L}$ in milk samples collected from animals reared in the vicinity of a $\mathrm{Pb}-\mathrm{Zn}$ smelter. These authors report much higher $\mathrm{Pb}$ levels than those obtained in our study.

At present, there are no maximum residue levels (MRLs) for trace elements in milk; Codex Alimentarius Commission (2007) only establishes a limit for $\mathrm{Pb}$ in milk (MRL $=0.02 \mathrm{mg} / \mathrm{kg}$ ). None of the $\mathrm{Pb}$ values in the samples tested exceeded this limit. For safety of human consumption, it would be advisable to establish MRLs for trace elements in milk and other dairy products.

\subsection{Comparison of trace elements level from different dairy farms}

Concentrations of trace elements in milk samples (Table 3) from eight dairy farms were statistically evaluated to find out whether the observed differences in analytical results are significant. There were no significant differences observed in the $\mathrm{V}$ concentrations in milk samples from farm 2 and farm 7 at the $95 \%$ confidence level. However, $V$ concentration in milk samples collected from farms 2 and 7 was significantly $(P<0.05)$ lower than the concentrations of $\mathrm{V}$ in milk samples from farm 1 (old gold and silver mining area), farm 3 (close to main road), farm 4 (metropolitan area), farm 5 (vanadium and chromium mining area), farm 6 (vanadium and chromium mining area), and farm 8 (vanadium and chromium mining area).

The mean concentrations of $\mathrm{Cr}$ in milk samples from farms $1,3,4,6$, and 8 were significantly higher than those in farms 2 and $7(P<0.05)$. But no significant difference was observed between concentrations of $\mathrm{Cr}$ in milk samples from farms 2,5 , and 7 at the $5 \%$ level of significance. The observed data on the $\mathrm{Mn}$ level showed no significant difference $(P>0.05)$ among farms 2,4 , and 5 . Whereas, the $\mathrm{Mn}$ mean concentrations in milk samples from farms $1,3,6,7$, and 8 revealed significant difference $(P<0.05)$ compared to its concentration in milk samples from farms 2,4 and 5 .

Sr concentrations in milk samples from farms $1,2,3,7$, and 8 are not significantly different at the $95 \%$ confidence level. However, levels of $\mathrm{Sr}$ in milk samples from farms 4-6 were significantly $(P<0.05)$ higher than its level in milk samples from farms $1,2,3$ and 7 . Cd was below detection limit in all milk samples $(<0.006)$. $\mathrm{Pb}$ was detected in milk samples from farms 1,3 , and 5 (Table 3 ) and the $\mathrm{Pb}$ levels showed significant variation among these farms at a $5 \%$ level of significance.

In general, the results of the one-way parametric ANOVA of trace elements in milk samples showed spatial variability at the $95 \%$ confidence level in the variances of $\mathrm{V}, \mathrm{Cr}, \mathrm{Mn}, \mathrm{Sr}$, and 
$\mathrm{Pb}$. This indicates that different milk samples may have different chemical compositions and may, thus, cause potentially different levels of exposures to toxic elements.

\section{Conclusions}

As the ICP-MS data were validated for trace elements by analysis of certified reference material of whole milk powder, it was concluded that the new method is accurate. The ANOVA results suggest that there were significant variations in the levels of some trace elements in milk samples from different dairy farms and this could be attributed to the different environmental conditions on these farms. It is suggested that the method described, using freeze drying and ICP-MS, be considered as a standard method for determining toxic metal residues in milk for enforcement of regulatory standards and assessing the risk of long-term exposure.

Further epidemiological studies with larger samples of milk from different areas are suggested, as well as correlation with geographical maps showing distribution of elements in soil and water.

\section{Acknowledgements}

Financial support from National Research Fund (NRF) and Tshwane University of Technology (TUT) is gratefully acknowledged. We thank the farms that have kindly cooperated in collecting samples.

\section{References}

1. Al-Awadi, F. M., \& Srikumar, T. S. (2000). Trace-element status in milk and plasma of Kuwaiti and non-Kuwaiti lactating mothers. Nutrition, 16, 1069-1073.

2. AOAC (1990). Official methods of analysis (15th ed.). USA: Association of Official Analytical Chemists.

3. Caggiano, R., Sabia, S., Emilio, M. D., Macchiato, M., Anastasio, A., Ragosta, M., et al. (2005). Metals levels in fodder, milk, dairy products, and tissues sampled in ovine farms of Southern Italy. Environmental Research, 99, 48-57.

4. Codex Alimentarius Commission (1998). Report of the twenty-second session of the Codex committee on methods of analysis and sampling. Budapest, Hungary, 23-27 November 1998.

5. Codex Alimentarius Commission (2007). Joint FAO/WHO food standards programme. Codex committee on methods of analysis and sampling, twentyeighth session, Budapest, Hungary, 5-9 March 2007.

6. Coni, E., Bocca, A., Coppolelli, P., Caroli, S., Cavallucci, C., \& Marinucci, M. T. (1996). Minor and trace element content in sheep and goat milk and dairy products. Food Chemistry, 57(2), 253-260.

7. Coni, E., Bocca, A., lanni, D., \& Caroli, S. (1995). Preliminary evaluation of the factors influencing the trace element content of milk and dairy products. Food Chemistry, 52, 123-130.

8. Coni, E., Caroli, S., lanni, D., \& Bocca, A. (1994). A methodological approach to the assessment of trace elements in milk and dairy products. Food Chemistry, 50, 203210.

9. Evans, E. H., \& Giglio, J. J. (1993). Interferences in inductively coupled plasma mass spectrometry, a review. Journal of Analytical Atomic Spectrometry, 8, 1-18http:// www.idfa.org/facts/milk/milkfact/milk5.pdf. Accessed 25.06.07.

10. Kira, C. S., \& Maio, F. D. (2004). Comparison of partial digestion procedures for determination of $\mathrm{Ca}, \mathrm{Cr}, \mathrm{Cu}, \mathrm{Fe}, \mathrm{K}, \mathrm{Mg}, \mathrm{Mn}, \mathrm{Na}, \mathrm{P}$, and $\mathrm{Zn}$ in milk by inductively coupled plasma optical emission spectrometry. Journal of AOAC International, 87(1), 151-156.

11. Liu, Z. P. (2003). Lead poisoning combined with cadmium in sheep and horses in the vicinity of non-ferrous metal smelters. The Science of the Total Environment, 309, 117-126.

12. Martino, F. A. R., Sánchez, M. L. F., \& Medel, A. S. (2000). Total determination of essential and toxic elements in milk whey by double focusing ICP-MS. Journal of Analytical Atomic Spectrometry, 15, 163-168. 
13. Martino, F. A. R., Sánchez, M. L. F., \& Sanz-Medel, A. (2001). The potential of double focusing ICP-MS for studying elemental distribution patterns in whole milk, skimmed milk and milk whey of different milks. Analytica Chimica Acta, 442, 191-200.

14. McKinstry, P. J., Indyk, H. E., \& Kim, N. D. (1999). The determination of major and minor elements in milk and infant formula by slurry nebulisation and inductively coupled plasma optical emission spectrometry. Food Chemistry, 65, 245-252.

15. Melaku, S., Wondimu, T., Dams, R., \& Moens, L. (2004). Simultaneous determination of trace elements in Tinishu Akaki river water sample, Ethiopia, by ICP-MS. Canadian Journal of Analytical Sciences and Spectroscopy, 49(6), 374-384.

16. Muñoz, E., \& Palmero, S. (2004). Determination of heavy metals in milk by potentiometric stripping analysis using a home-made flow cell. Food Control, 15, 635-641.

17. Onianwa, P. C., Adetola, I. G., Iwegbue, C. M. A., Ojo, M. F., \& Tella, O. O. (1999). Trace heavy metals composition of some Nigerian beverages and food drinks. Food Chemistry, 66, 275-279

18. Saleh, M. A., Ragab, A. A., Kamel, A., Jones, J., \& El-Sebae, A. K. (1996). Regional distribution of lead in human milk from Egypt. Chemosphere, 32(9), 1859-1867.

19. Salma, I., Maenhaut, W., Dubtsov, S., Papp, É. Z., \& Záray, G. (2000). Impact of phase out of leaded gasoline on the air quality in Budapest. Microchemical Journal, $67,127-133$.

20. SAS Institute Inc. (2001). The SAS system for windows V8. Cary, NC, USA: SAS Institute Inc.

21. Smit, L. E., Schönfeldt, H. C., de Beer, W. H. J., \& Smith, M. F. (2000). The effect of locality and season on the composition of South African whole milk. Journal of Food Composition and Analysis, 13, 345-367.

22. Sowers, M. R., Scholl, T. O., Hall, G., Jannausch, M. L., Kemp, F. W., Li, X., et al. (2002). Lead in breast milk and maternal bone turnover. American Journal of Obstetrics and Gynecology, 187(3), 770-776.

23. Swarup, D., Patra, R. C., Naresh, R., Kumar, P., \& Shekhar, P. (2005). Blood lead levels in lactating cows reared around polluted localities transfer of lead into milk. Science of the Total Environment, 349, 67-71.

24. Tripathi, R. M., Raghunath, R., Sastry, V. N., \& Krishnamoorthy, T. M. (1999). Daily intake of heavy metals by infants through milk and milk products. The Science of the Total Environment, 227, 229-235.

25. Underwood, E. (1977). Trace elements in human and animal nutrition (4th ed.). New York, USA: Academic Press.

26. Vanhaecke, F., Vanhoe, H., \& Dams, R. (1992). The use of internal standards in ICPMS. Talanta, 39(7), 737-742.e heavy metals composition of some Nigerian beverages and food drinks. Food Chemistry, 66, 275-279.

Table 1

Instrumental operating conditions of PerkinElmer ELAN DRC-e ICP-MS

\begin{tabular}{|ll|}
\hline Operating parameter & Setting \\
\hline Plasma power output & $1300 \mathrm{~W}$ \\
RF generator frequency & $40 \mathrm{MHz}$ \\
Analog stage voltage $(\mathrm{V})$ & -1850 \\
Pulse stage voltage $(\mathrm{V})$ & 800 \\
Main water temperature $\left({ }^{\circ} \mathrm{C}\right)$ & 19 \\
Interface water temperature $\left({ }^{\circ} \mathrm{C}\right)$ & 31 \\
Torch box temperature $\left({ }^{\circ} \mathrm{C}\right)$ & 32 \\
Lens voltage $(\mathrm{V})$ & 7 \\
Argon flow rate $\left(\mathrm{L}\right.$ min $\left.^{-1}\right)$ & Plasma: 15 , auxiliary: 1.2 , nebuliser: $0.89-1.02$ \\
Nebuliser type & Cross-flow \\
Spray Chamber type & Ryton ${ }^{\circledast}$, double-pass \\
Interface & Ni sampler and skimmer cones, i.d. 1.1 and 0.9 mm, respectively \\
Torch & Standard quartz torch \\
Data acquisition & Peak hopping; dwell time per AMU $40 \mathrm{~ms}$, sweeps/reading 60, number of replicates 3 \\
\end{tabular}

Table 2

Detection limit $(\mathrm{lg} / \mathrm{L})$ of the procedure and analysis of whole milk powder standard reference material (SRM 8435)

\begin{tabular}{|llll|}
\hline Element & $\mathrm{DL}$ & Concentration $\mathrm{in} \mathrm{mg} / \mathrm{kg}$ & \\
\hline & & Observed & Certified \\
\hline $\mathrm{V}$ & 0.016 & $\mathrm{na}$ & $\mathrm{na}^{\mathrm{a}}$ \\
$\mathrm{Cr}$ & 0.09 & $0.43 \pm 0.04$ & 0.5 \\
$\mathrm{Mn}$ & 0.103 & $0.15 \pm 0.04$ & $0.17 \pm 0.05$ \\
\hline
\end{tabular}




\begin{tabular}{|c|c|c|c|}
\hline $\mathrm{Sr}$ & 0.163 & $4.03 \pm 0.31$ & $4.35 \pm 0.50$ \\
\hline $\mathrm{Cd}$ & 0.006 & $<0.006$ & 0.0002 \\
\hline $\mathrm{Pb}$ & 0.136 & $0.096 \pm 0.007$ & $0.11 \pm 0.05$ \\
\hline
\end{tabular}

${ }^{\text {a }}$ na - not available

Table 3

Concentrations of trace elements in raw cow's milk samples

\begin{tabular}{|c|c|c|c|c|c|c|c|}
\hline \multirow[t]{2}{*}{ Dairy farm } & \multirow[t]{2}{*}{ Sample ID } & \multicolumn{6}{|c|}{ Concentrations of elements in $\mathrm{ng} / \mathrm{g}$ dry weight (mean $\pm \mathrm{SD}$ ) } \\
\hline & & $\mathrm{V}$ & $\mathrm{Cr}$ & $\mathrm{Mn}$ & $\mathrm{Sr}$ & $\mathrm{Cd}$ & $\mathrm{Pb}$ \\
\hline \multirow[t]{3}{*}{ Farm 1} & S11 & $40.0 \pm 0.73$ & $362 \pm 25$ & $238 \pm 8.9$ & $2110 \pm 63$ & $<0.006$ & $8.97 \pm 0.56$ \\
\hline & $\mathrm{S} 12$ & $40.7 \pm 0.69$ & $368 \pm 20$ & $236 \pm 9.3$ & $2120 \pm 84$ & $<0.006$ & $8.00 \pm 0.60$ \\
\hline & $\mathrm{S} 13$ & $40.6 \pm 1.3$ & $371 \pm 18$ & $243 \pm 6.4$ & $2140 \pm 74$ & $<0.006$ & $8.78 \pm 0.38$ \\
\hline \multirow[t]{3}{*}{ Farm 2} & $\mathrm{~S} 21$ & $26.5 \pm 1.6$ & $229 \pm 15$ & $169 \pm 7.9$ & $2170 \pm 77$ & $<0.006$ & $<0.136$ \\
\hline & S22 & $25.2 \pm 1.8$ & $233 \pm 15$ & $170 \pm 7.7$ & $2200 \pm 74$ & $<0.006$ & $<0.136$ \\
\hline & $\mathrm{s} 23$ & $24.9 \pm 2.0$ & $215 \pm 10$ & $172 \pm 7.3$ & $2174 \pm 55$ & $<0.006$ & $<0.136$ \\
\hline \multirow[t]{3}{*}{ Farm 3} & S31 & $29.7 \pm 2.6$ & $349 \pm 8.0$ & $228 \pm 5.6$ & $1880 \pm 82$ & $<0.006$ & $19.4 \pm 1.1$ \\
\hline & S32 & $29.4 \pm 2.7$ & $358 \pm 7.5$ & $229 \pm 6.1$ & $1910 \pm 45$ & $<0.006$ & $\overline{19.7 \pm 1.1}$ \\
\hline & S33 & $29.0 \pm 2.6$ & $355 \pm 8.8$ & $231 \pm 4.6$ & $1910 \pm 46$ & $<0.006$ & $19.7 \pm 1.4$ \\
\hline \multirow[t]{3}{*}{ Farm 4} & S41 & $35.1 \pm 2.03$ & $55 \pm 20$ & $167 \pm 10$ & $2690 \pm 81$ & $<0.006$ & $<0.136$ \\
\hline & S42 & $35.9 \pm 2.3$ & $358 \pm 19$ & $166 \pm 11$ & $2720 \pm 110$ & $<0.006$ & $<0.136$ \\
\hline & S43 & $34.5 \pm 1.4$ & $353 \pm 17$ & $170 \pm 7.7$ & $2660 \pm 76$ & $<0.006$ & $<0.136$ \\
\hline \multirow[t]{3}{*}{ Farm 5} & S51 & $32.0 \pm 1.5$ & $292 \pm 9.9$ & $161 \pm 6.7$ & $2510 \pm 170$ & $<0.006$ & $14.2 \pm 1.2$ \\
\hline & S52 & $27.0 \pm 0.32$ & $277 \pm 9.7$ & $157 \pm 8.1$ & $2590 \pm 180$ & $<0.006$ & $11.9 \pm 1.8$ \\
\hline & S53 & $31.0 \pm 1.6$ & $208 \pm 13$ & $181 \pm 7.8$ & $2940 \pm 140$ & $<0.006$ & $17.9 \pm 0.85$ \\
\hline \multirow[t]{3}{*}{ Farm 6} & $\mathrm{~S} 61$ & $31.8 \pm 1.2$ & $350 \pm 6.2$ & $213 \pm 18$ & $3150 \pm 76$ & $<0.006$ & $<0.136$ \\
\hline & S62 & $32.1 \pm 0.28$ & $339 \pm 3.3$ & $180 \pm 5.7$ & $2660 \pm 180$ & $<0.006$ & $<0.136$ \\
\hline & $\mathrm{S} 63$ & $32.1 \pm 0.37$ & $238 \pm 6.1$ & $198 \pm 14$ & $3050 \pm 190$ & $<0.006$ & $<0.136$ \\
\hline \multirow[t]{3}{*}{ Farm 7} & S71 & $25.6 \pm 1.2$ & $186 \pm 6.8$ & $109 \pm 1.6$ & $1900 \pm 69$ & $<0.006$ & $<0.136$ \\
\hline & S72 & $23.4 \pm 1.0$ & $265 \pm 13$ & $115 \pm 4.7$ & $2110 \pm 96$ & $<0.006$ & $<0.136$ \\
\hline & S73 & $23.9 \pm 0.43$ & $279 \pm 7.8$ & $116 \pm 4.3$ & $2130 \pm 78$ & $<0.006$ & $<0.136$ \\
\hline \multirow[t]{3}{*}{ Farm 8} & S81 & $38.0 \pm 1.5$ & $310 \pm 8.6$ & $299 \pm 11$ & $2810 \pm 150$ & $<0.006$ & $<0.136$ \\
\hline & S82 & $42.0 \pm 2.6$ & $362 \pm 11$ & $233 \pm 16$ & $2140 \pm 57$ & $<0.006$ & $<0.136$ \\
\hline & S83 & $37.3 \pm 2.1$ & $329 \pm 13$ & $257 \pm 18$ & $2460 \pm 140$ & $<0.006$ & $<0.136$ \\
\hline
\end{tabular}

